\title{
The New Regulatory Concerns and Regulatory Management
}

\author{
Gouher Ahmed \\ Al Ghurair University, Dubai, United Arab Emirates
}

\begin{abstract}
The present study is attempts to investigate the global financial crisis of 2008, which originated in the United States of America and spread to other countries. This global financial crisis was following the collapse of the mid-19th century financial giant on the September 15 of this year, other big banks also on the verge of collapse have raised concerns across the globe, especially in the United States of America, and also started to search for some unfailing financial regulations and financial authorities or regulators, but even amidst the countries like UAE and India were noted to be of comparative calm because of their principled banking and central banks, and the results found out to be mostly as a failure of bank leadership, especially of central banks like the US Fed, the unprincipled banking which is at the back of the crisis, and also an ineffective central banking, and the regulatory search is led to central banking and dynamic regulatory management (DRM).
\end{abstract}

Keywords: international business, global financial crisis, regulatory management, banking principles, ethics

\section{Introduction}

When the world was thought to be advancing well under the new market ideology of the west, of which the USA is supposed to be the main proponent-in the 21st century, it was struck in 2008 by financial crisis of the magnitude of the Great Depression of the 1930s, starting with the No.1 economy of the world of the USA spreading to the rest of the world like a wild-fire, from the devastations of the US to the rest of the world which have yet to recover. For example, the rate of unemployment in the US is said to be running at the yet unmaintainable level of 9.1\% in August 2011 (U.S BLS, 2012), not to say the other less “robust” countries and economies. Democratic India too has yet to hit its pre-2008 near to double digit growth rate of 9 percent plus, notwithstanding its self-acclaimed prudential financial management of the crisis and its international economic good behavior, according to principles of "free \& fair trade", unlike some nouveau rich countries aggrandizing themselves.

What is more, it is feared whether the Great Recession, a great calamity in itself would slide into a far great calamity of Great Regression, according to some straws in the wind.

After the Great Recession, Europe has embarked on a Great Regression. Wages, Pensions, unemployment insurance, welfare benefits and collective bargaining are under attack in many areas as governments struggle to reduce debt swollen partly by the cost of rescuing banks during the global financial crisis. (Taylor, 2011, p. 12)

So, it is banks at the center of the crisis that called for not only rescue but also regulation to see that such

Gouher Ahmed, Ph.D., PMP, Associate Professor of Strategy and International Business, College of Business Studies, Al Ghurair University.

Correspondence concerning this article should be addressed to Gouher Ahmed, P.O. BOX: 37374 Dubai, United Arab Emirates. E-mail: gouher@agu.ac.ae; gouher@usa.net. 
crises which do not take place hence. But, in the near future, the present crisis is to be fought off. Following this concern exercising G-20, IMF, IBRD, banking, and academic circle too, this note is addressed to the new financial regulatory concerns, regulations, and regulatory management that appear to be eluding a consensus. It is the nature of the crisis that the regulatory remedy or remedies to put into effect. The big crisis itself after has so much experience and expertise of running the financial institutions, then regulation appears to have no cause when everything appeared to be running well under the new international economic order of globalization, privatization, competitions, free and fair trade, etc. (Paul, 2008). However, the free-market ideology, which calls for a lot of self-discipline and self or voluntary regulations on the part of all its players, should not be interpreted to do anything in pursuit of profits. Accordingly, the new regulatory concerns assume the importance for an academic investigation, with the objective of unraveling the nature of crisis and whether right remedies are being sought in the new regulatory searches. The exercise may start with a note of the objectives and methodology of this modest exercise.

\section{Objectives}

- To understand the nature of the great crisis;

- To know whether the regulators were helpless against the crisis and its alleged authors or perpetrators;

- To fathom the new regulatory concerns and regulatory remedies;

- To outline the nature of regulatory management that would take care of great crisis and their formidable players;

- To draw lessons from the crisis for policy and regulation.

\section{Methodology}

In the first place, it is the free market ideology giving a freehand to the market players as the benefactors of mankind which is at stake and is to be examined. Does it mean regulatory helplessness? This question is to be addressed. Next, it is the question of banking, particularly big banks, which is said to be at the heart of the crisis, but banking is well-established economic setup which is the guardian of public money which should be the last or never to stray away from the path of trusteeship. So, along with the free market ideology, the question of banking and banking standards are also gone into, in the breach of which the whole problem of the crisis appears to lie in the fact that the failure of central banking to uphold the principles of banking. It also argues whether the big bank means no principles of banking to follow. Than the great crisis itself is examined and the efforts at warding it off and the cost of the crisis in human and materials terms.

It is also well known that there is a crisis-within the crisis, debt crisis, under which government are reeling under it and being bailed out by the IMF and following government movements such as that of the EU, quite reluctantly, and which are running budgetary and trade deficits, including India. There are also regulatory concerns on this bigger score (Krugman, 2011).

As such, regulatory concerns, arising out of the great crisis-2008, are very much in the air not only at the national level but also at the international level of which a view is taken, as also of attempts at new regulatory bodies or super or unfailing regulators that would make the world safe from big or great financial or banking and debt and budgetary crisis. Not the least is the Regulatory Architecture or Management (RM) that is to emerge from the new regulatory concerns and regulations. 
Finally, the method of the study is to see whether the new regulatory concerns remedial concerns and measures and architecture meet the basic problem of the crisis which appears to be the regulatory failure itself, self and of the regulatory authorities. Why, for example, entities like the UAE are free from the regulatory concerns' show they could have a safe sail through the crisis? The case of India is not different, where there are no regulatory concerns. It is a different thing that the government of India, for no reason but just to assert itself unnecessarily and against a good working central bank, appears to be thirsting for one and two regulatory concern. Indian is a case of petty political over lordism in the crisis to rule over a good working central bank. The roots of the crisis are deep and abutting that need to be taken a view. Why, again the US neighbor-Canada has no regulatory concerns and appears to be calm amidst the raging financial storm just in the neighborhood. In the light of this, the new regulatory concerns may appear panic reactions, which, in retrospect, may seem unmissed for it.

\section{Market and Banking Ideology}

There is no doubt that the winds of change blowing across the continents and countries, bringing the countries together, the winds of globalization, marketization, privatization, enterprise, innovations, mobility, internet, mobile phones, international business, travel, tourism and education, free trade, consumerism, advertisement, enterprise, rising aspirations, environmental concerns, space exploration, etc.. The economic dictum of this new world economy is the rule of the invisible hand or price mechanism, an all time and seemingly an ever alluring accept of Adam Smith (1723-1790), the author of the foundational classic of the science of economics as well as business The Wealth of Nations [1776] (Smith, 1776). Notwithstanding its critics, the ideology by and large continues to dominate the domain of economic policies and practices (The Economist, 2001). It needs no saying that the market ideology is for high growth, greater trade, and more welfare, for ushering in, in short, an era of global prosperity. It is well known that the late Prof. C. K. Prahalad, the management doyen, had called upon the business in general and MNCs in particular to advance their footsteps towards the bottom of the economic pyramid (BOP) which made up of the world's poor and produce goods and services for the poor by somewhat lowering their high profit expectations (Prahalad, 2004). Prof. Prahalad's concept is a great innovation in economic and business with a great humanizing effect, lending the new market ideology to be a human face and a concern for the welfare of humanity at large. The market theory is for unleashing enterprises and innovations. It has brought, among other things, mobiles at a cost of Rs. 500 or $\$ 11$ a piece within the reach of the common man in India, a country of great poverty numbers. The Crisis raises doubts concerning the free market ideology (Economic \& Political Weekly, 2009) whether it is time for a counter-revolution is a different thing. There is, however, no doubt about the crisis raising regulatory concerns. One thing overlooked concerning the free market ideology by all the players is self-discipline and umpiring, and nobody big enough to break the market code. In fact, the bigger enterprises have greater responsibility thrust on them. They are the uncrowned market leaders who set example in good business behavior for the rest. They are economic light-houses who should strike a right path for themselves and the rest. They are business leaders. No business or profit at the cost of the public good and general welfare, which is not philosophy or ethics but fundamental market and business principle. Banking, especially, should be the embodiment of all this time principle. No tampering, hanky-panky. The foundation of banking is PUBLIC TRUST. They should set up financial standards and norms of good financial behavior. There is an unbreachable banking code. If anything, the crisis appears to teach that the bankers, especially the so-called big bankers, need to taught the banking 
principles. It is an unfortunate situation that even the great central bankers appear to be in need of learning the banking principles and the principles of central banking. There is no such thing as free-for-all-banking.

\section{Banking Principles}

It may seem to belabor the obvious to talk about the banking principles to the management community, but it is the breach of these age-old, trusted principles which is the heart of the big or the first big financial turmoil of the 21st century and all efforts at the national and international level are being expended to invent a financial regulatory - Holy Grail(s) align to a wild-goose chase. After all, for all these years, especially in the greatly inventive 22nd century, the world has not been living in financial regulatory dark times. The world had lived through the far greater financial crisis of the great depression. It is now only great recession, somewhat a lesser calamity. Eternal vigilance, they say, is the price of democracy, the winds of which appear to be blowing across the seemingly democratically arid Arab World. Free market ideology and system is alien to economic democracy that needs to be eternally guarded. But, the Guards, the bankers, viz. the central bankers appear to be off the duty - the mighty Fed, the historical and imperial BOE and the no less distinguished BOJ, which, it appears, need to learn from their lesser brethren like the Reserve bank of India (RBI) that had stood tall and firm during the crisis. No less is the role played by central banking in the UAE - the entity of about four decades. They are the examples of good banking.

Whatever it may be, no sub-prime loans, at the heart of financial crisis, banking calls upon among the banking principles nor putting all investment eggs in one basket-In the crisis in housing (Sowell, 2009), nor passing the buck on to the unsuspecting public around the world in the form of mortgaged back (un) securities or derivatives. "The 'creative' financing of home mortgages and the marketing of financial securities based on American mortgages around the world are part of the story of how a financial house of cards was built up and then suddenly collapsed" (Financial Express, 2009).

Banks should reach out to the general public and make them to be a partner in their business, of which the first is mobilization of deposits - the stock in trade of banks. It is needless to say is for the BOP or inclusive banking or banking inclusive of the common man saving, Deposits, as such, are the first principle of banking (The Penguin Dictionary of Economics, 1972), from which the rest of the banking principles follow-Liquidity, Security, Prudence, Economy, Reserves, Sound Investment, Due Diligence, Trusteeship, Public Confidence, Low Profile, Productivity, Credit creation, Monitoring, Mortgages, Credit Counseling, Recoveries, Deposit and Interest Rates, Profit Margins, CEO Pay and Bonuses and Perks. The Golden Rules of Banking are liquidity, Security, Profitability, and Public Trust.

Above all, the central banks should stand tall and see that however their constituent banks are big and trying to be forbidding on the right lines and are not an authority and law unto themselves. The real regulatory measures in the given circumstances would be to create a Regulator of Central Bank, say, Fed Regulator or Regulatory Authority, a ridiculous proposition. The mandate of central banking is banking governance beyond all hum-drum politics and politicking. Central Banks are begin to be banking rulers and overlord with carrot-and-stick. The Fed should have heard quite in advance the tolling of the bells of the impending crisis.

Here is the great economist the late Prof. Samuelson has to say about the Fed-Federal Reserve System, the US Central Bank, generally acknowledges to the first of the Central banks of the developed world, where decisions have world-wide repercussions. The Fed is said to be interested in the interest of the American public 
and always acts in their favor (Samuelson, 1980). But it appears to have failed in the present crisis daily costing huge to the US public.

In 1913, Congress created a Federal Reserve Act, signed by President Wilson. The reform sprang from the panic of 1907, with the alarming epidemic of bank failures. After half a dozen years' agitation and discussion by both parties, the Federal Reserve System was formed-in face of strong banker opposition. (p. 275)

So any banking reforms and regulations are not easy.

The Fed is a public agency, its role has expanded over the years (MacDonald \& Koch, 2006), but its primary focus has remained the same, and the Fed is directly responsible for Congress, and whenever any conflict arises between its making a profit and the public interest. It acts according to the public interest without question. It is in fact, one of the most eminent public institutions of the US. Although the President appoints the Board of Governors and considers that its allegiance is primarily to congress and not to the executive branch.

This is not intended to be an easy thing on Banking and Central banking, but on the big financial or banking crisis of 2008 and the regulatory concerns raised by it and the search on for new regulations and regulatory bodies, which even if necessary are not going to be an easy sailing in the light of the seemingly "sovereign" of big banks and their rightist or ultra rightist political pals. The battle for any regulations or regulatory bodies is most likely to be lost, at the very thought stage. It is not the intention to paint a dark or darker picture of the troubled situation, but to bring home human and leadership failure(s). There is no lack of "weapons" of bank and credit regulation—both major and minor. There is the minor but powerful weapon of "Moral suasion" to make the banks see reason and the writing on the wall, from indulging in any unbanking practices. This does not appear to have been used by any during or after the present crisis. It is the weapon of last resort, a powerful weapon which puts the guilty and the culprit at the bar of public opinion and makes the things known to the banking and the general public and all stakeholders. As it is, the bank' CEO appear to be in low public estimation. The general consensus is that the crisis is owing to the bankers "greed" and unbanking practices. Both CEO royalism does not seem to impress the general public.

\section{The Big Crisis}

Among the results of the crisis is the output of large "crisis literature", which is not to be at an end for quite some time to come. "The economic recession that the world stumbled into seems to have caused larger damage to the forests than banks, the 'recession literature' it is already packed to rafters” (Jagannath, 2011). There may be a larger picture involved in the crisis, as the crisis may be depicted as the crisis of capitalism. There are forever capitalism bashers, but the system is instead of collapsing or exhibiting any signs of collapse even getting back to its feet. The over-riding factors or the factors in all the exercise regarding the crisis is sub-prime or bad or un-maintainable or ineligible loans quite overwhelmingly to the single sector of housing from the start of the 21st century in the United States of America and elsewhere. This breaches the banking rule of not putting all eggs in one basket, so theoretically and practically quite an untenable banking proposition for any good length of time. It is a case of infirm or bad credit management. Sub-Prime loans are not at all in the banking lexicon. Do the banks need to be told these basic principles of banking in India, the RBI-Reserve Bank of India cautious the banks to be wary of real estate loans. Then, during the crisis, the RBI has had the good fortune of good leaders or Governors-D. Subba Rao and his predecessor Y.V. Reddy. Dr. Reddy was taken to be a crisis averting central banker by no less than an authority than Prof. Stiglitz, an Economics Nobel Laureate. Then the crisis boils down to the crisis in central banking leadership. It is Prof. Krugman's constant 
thesis and refrain that the crisis is entirely the work of the big US bankers. He has very strong words for them, such as looters. His almost seemingly single-point program of banking reform and regulation is banker's compensation (Krugman, 2009). Prof. Krugman too is an Economics Laureate and a people's economist whose opinions cannot be brushed aside as partisan or ideological. The Fed and its leadership are not spared. In his view, the Fed is awakening from its slumber and thinks that the banker's compensations too fall within its regulatory purview as a measure of preventing reckless banking. For "royal” pay and perks, bonuses, house furnishings, paid holidays, private jets, etc., also, it needs no elaboration, and does not fall within the principles of sound banking, The US public appears to be palpably furious about the banking royalty. The fury is directed against the presidency and Fed for not disciplining the big businesses.

From the first (Semmler, 2009) to the latest (Bartiromo, 2011) stories of the crisis point to the deliberate breaking of the banking principles as the proximate cause of the crisis, starting with the lack of saving drive to excessive leveraging, non-prime or subprime loans, heavy housing loans, heavy risk taking, complex securities, the outsourcing of risk, fat pay packs and large bonuses, poor CRM deception, cut throat competition, and bad leadership worse are the accusations of fraud against the big Businesses of the United States of America, the banking of which should set a model not of democratic banking, the United States of America standing for the cause of democracy world over and which is the bond of affinity between the US and India. It is reported to be a big public furor and wrath against the big banking of America from their own people which should be an enough cause for deep introspection and self reform and regulations, beyond any government regulatory concerns, reforms, and measures. The public appears to be equally or palpable against the great Fed and its celebrity leadership. The great Greenspan, the ex-Fed, head appears to be no more than a national icon, and the current head Ben Bernanke, an academic, just scraped through the senate for his second term. The role of the fellow bankers in the collapse of the 19th century origin from Lehman September 15th, 2008, heralding the financial crisis of nearly a century is claimed to be no less than that of the Richard Fuld, Lehman CEO, and rated No. 1 among the best American CEOs. The crisis sounds a great human drama disappointment with the charismatic President Obama seems to be no less, with his putting of health reforms as No. 1 program of his Administration amidst the big crisis. For, while the importance of a public health program cannot either be discounted or ruled out, the crisis should have been addressed first. That is, First Things First. The president, it seems was vetoed down in the Massachusetts senate election in January 2010 wherein democratic stronghold, the democratic candidate, a lady, had to give into the Republican one, spurring the president to financial regulatory concerns and reforms after nearly one and a half years of crisis, during which time massive bailouts were being handed over to the "too big to fail" (too big to reform and regulate too?) banks by the Fed and the Treasury, denting a big deficit hole in the budget to be called a bailout budget, bailouts 1.25 tr. and deficit 1.35 tr. (Financial Express, 2010). The crisis is compounded by the budgetary and trade deficits.

The US macroeconomic fundamentals are indicative of policy shifts that occurred just after the turn of the Century toward fiscal and monetary excess. “Twin deficits” have characterized the US economy after 2001.The current account deficit reflects the imbalance between US national savings and investment, which takes into account both government and private saving and investment balance.

The twin deficits as well as banking lapses, by and large, point to leadership failure for which there cannot be any regulatory remedy, leaving the lapses of political or presidential leadership aside for the time being, before, during as well after the crisis lapse of central banking leadership is most telling, especially in the light 
of the well known Davos or WEF consensus for strong, proactive central banks or more appropriately central bankers. Hence, the lament of D. Subbarao, Governor, Reserve Bank of India over the loss of creditable of central banks during the crisis (Subbarao, 2010). Hence, any number of regulatory concerns arising out of the crisis (Reddy, 2010), from capital base to the quality of credit, quite understandably, but all falling to the lot of any central banks. Any financial regulations are sure to be met with stiff bankers' opposition as opposed to their freedom of enterprise. The crisis-born Reforms or Regulations, after a lot of deliberations and compromises also fall short of popular expectations, as, for example, leaving the crucial issue of banker's pay to the shareholders (Financial Express, 2010). Hence, what appears to be called for is central bank Dynamic Regulatory Management, the IMF, which also failed to throw any light in the troubled situation (Economic \& Political Weekly, 2011). The consequences of which are expected to be lost for quite some time.

\section{Dynamic Regulatory Management}

So the ball of crisis management and crisis prevention is thrown into the court of the central bank. It cannot abdicate its natural banking authority and responsibility to any other body. It is the public representative. Big banks should be model banks, as the SBI-State Bank of India, the biggest of all Indian banks and other nationalized and private and foreign banks of India, because the Reserve Bank of India is forever monitoring the situation.

Economic and business situation is ever changing, even keel through this changing situation by an appropriate and dynamic, democratic, and progressive regulatory management that is primitive of growth with equity. There should not be duplication of banking regulators or authorities. The principles of management are as much applicable to central banking as to business bodies. However public welfare replaces profit motive.

\section{Conclusions}

The Global Financial Crisis of 2008, signaled by the fall of Lehman Brothers on September 15, 2008, has many lessons to impart to the politicians, policy makers and bankers and central bankers, to the last, mainly. The crisis, called Great Recession, falls within the domain of central banking. It is the result of breaking all banking principles, with unbridled competition and a seemingly insatiable thirst for profits and fat pay, bonus and perks that do not fall within the ambit or democratic banking. The crisis has raised regulatory concerns and search for unfailing banking regulations and regulatory authorities. The search leads to good old central banking and a dynamic regulatory management (DRM) by it.

\section{References}

Ahmed, G., \& Khanfar, M. (2012). New dimensions of business excellence. IJAS International Conference at Harvard University, Cambridge, Massachusetts, USA, May 27-May 31, 2012.

Asian Development Bank (ADB) (2008, December). The US Financial Crisis, Global Financial Turmoil, and Developing Asia. Is the Era of High Growth at an End? Working Paper No. 139.

Bartiromo, M. (2011). The Weekend That Changed Wall Street. U.S.A.: Penguin.

Economic \& Political Weekly. (2009, March 29). What way now? 46(13), 1-6.

Economic \& Political Weekly. (2011, February 19). IMF: An Inefficient Watchdog, 46(8), 8-9.

Financial Express. (2011, May 22). Overhauling finances (p. 8)

Jagannath, J. (2011). Weak end to the crisis sagas. Business Standard (p. 9).

Krugman, P. (2009, September). Reform or bust. New York Times (P. A23).

Krugman, P. (2011, February). Wisconsin power play. New York Times (p. A17).

MacDonald, S. S., \& Timothy, W. K. (2006). Management of Banking. O.H.: South-Western. 
Paul, J. (2008). Business environment-texts and cases (pp. 387-389). New Delhi: Tata McGraw-Hill.

Prahalad, C. K. (2004). The Fortunes at the Bottom of the Pyramid, Eradicating Poverty Through Profit. N.J.: Wharton School Publishing.

Reddy, Y. V. (2010, November). Need to strengthen financial regulation. Business Standard (p. 7).

Samuelson, P. A. (1980). Economics (p. 532). Tokyo: McGraw-Hill. Chapter on Banking and Central Banking.

Semmler, W. L. B. (2009). Banking, complex securities and the credit crisis. Economic \& Political Weekly, XLIV(13), $137-143$.

Smith, A. (1776). The wealth of nations (Reprint 2003). USA: Bantam Books.

Sowell, T. (2009). The Housing Boom and Bust. Basic Books.

Subbarao, P. (2010). Financial crisis dents credibility of central banks. The Hindu (p. 10).

Taylor, P. (2011). After the great recession, the great regression. Deccan Chronicle (p.12).

The Economist. (2001, October 4). Globalization and its critics (pp. 3-5).

The Penguin Dictionary of Economics. (1972). Vilking, New York (pp. 28-39) (Definition of Principle of Banking).

U.S. Bureau of Labor Statistics. (2012). Washington, D.C.. Retrieved 16 August, 2012, from http://www.bls.gov 